\title{
Comment on Klek et al. Enhanced Recovery after Surgery (ERAS) Protocol Is a Safe and Effective Approach in Patients with Gastrointestinal Fistulas Undergoing Reconstruction: Results from a Prospective Study. Nutrients 2021, 13, 1953
}

\author{
Augusto Lauro $^{1, *}$ and Maria Cristina Ripoli ${ }^{2}$ \\ 1 Department of Surgical Sciences "F. Durante", Sapienza University, 00185 Rome, Italy \\ 2 Ospedale "Ceccarini" di Riccione, 47838 Rimini, Italy; cristina-ri@hotmail.it \\ * Correspondence: augustola@yahoo.com
}

check for

updates

Citation: Lauro, A.; Ripoli, M.C.

Comment on Klek et al. Enhanced

Recovery after Surgery (ERAS)

Protocol Is a Safe and Effective

Approach in Patients with

Gastrointestinal Fistulas Undergoing

Reconstruction: Results from a

Prospective Study. Nutrients 2021, 13, 1953. Nutrients 2022, 14, 17. https:// doi.org/10.3390/nu14010017

Academic Editor: Misha D. P. Luyer

Received: 20 July 2021

Accepted: 13 December 2021

Published: 22 December 2021

Publisher's Note: MDPI stays neutral with regard to jurisdictional claims in published maps and institutional affiliations.

Copyright: (C) 2021 by the authors. Licensee MDPI, Basel, Switzerland. This article is an open access article distributed under the terms and conditions of the Creative Commons Attribution (CC BY) license (https:// creativecommons.org/licenses/by/ $4.0 /)$.
We read and appreciated the prospective study by Klek et al. [1] recently published in Nutrients: an ERAS (Enhanced Recovery After Surgery) protocol was used by the authors to reduce post-operative complications in all subjects scheduled for surgery due to enterocutaneous fistulas, collecting a consecutive series of 100 patients between 2011 and 2020 . The ERAS protocol was successfully applied even though few modifications of the original plan were introduced in 2015, dividing the patients in two groups (2011-2015 and 20162020): a statistically significant improvement of surgical outcomes was shown by the authors, reporting a reduction of postoperative nausea and vomiting, overall complication rate, and median length of hospital stay (overall and after surgery).

We do agree that ERAS protocols have demonstrated their efficacy after colorectal surgery [2], but the unquestionable novelty of the study by Klek et al. requires further discussion. Surgery for entero-cutaneous fistulas represents a challenge [3,4]: in our previous systematic review of the literature on this topic [5], we included in our study 1217 patients. A bowel resection with primary anastomosis was performed in 1048 patients, and 856 patients $(81.7 \%)$ had a fistula takedown in one procedure without a temporary covering stoma. The patients had $14.3 \%$ recurrence and $13.1 \%$ mortality rate respectively.

Our question to the authors is related to their surgical technique. They [1] reported a $0 \%$ mortality rate in both groups and an overall complication rate of $34.4 \%$ and $14.5 \%$ in group 1 (2011-2015) and group 2 (2016-2020), respectively. Their outcome is clearly improved compared to international literature and to their initial series along the years, but it would be very interesting to let the reader know if they performed a temporary stoma to cover their anastomoses or not.

The matter does not represent a futile topic under the clinical point of view: a staged operation [6] or primary anastomosis without stoma [5] could determine relevant implications on the patient' recovery, and these factors should be considered to fully evaluate the modified ERAS protocol as safe and effective in patients treated for gastrointestinal fistulas.

We thank in advance the authors for their kind reply and congratulate them for their pioneering report in such a demanding and controversial field.

Funding: This research received no external funding.

Conflicts of Interest: The authors declare no conflict of interest. 


\section{References}

1. Klek, S.; Salowka, J.; Choruz, R.; Cegielny, T.; Welanyk, J.; Wilczek, M.; Szczepanek, K.; Pisarska-Adamczyk, M.; Pedziwiatr, M. Enhanced Recovery after Surgery (ERAS) Protocol Is a Safe and Effective Approach in Patients with Gastrointestinal Fistulas Undergoing Reconstruction: Results from a Prospective Study. Nutrients 2021, 13, 1953. [CrossRef] [PubMed]

2. Gustafsson, U.O.; Scott, M.J.; Hubner, M.; Nygren, J.; Demartines, N.; Francis, N.; Rockall, T.A.; Young-Fadok, T.M.; Hill, A.G.; Soop, M.; et al. Guidelines for Perioperative Care in Elective Colorectal Surgery: Enhanced Recovery After Surgery (ERAS ${ }^{\circledR}$ )Society Recommendations: 2018. World J. Surg. 2019, 43, 659-695. [CrossRef] [PubMed]

3. Owen, R.M.; Love, T.P.; Perez, S.D.; Srinivasan, J.K.; Sharma, J.; Pollock, J.D.; Haack, C.I.; Sweeney, J.F.; Galloway, J.R. Definitive surgical treatment of enterocutaneous fistula: Outcomes of a 23-year experience. JAMA Surg. 2013, 148, 118-126. [CrossRef] [PubMed]

4. Ravindran, P.; Ansari, N.; Young, C.J.; Solomon, M.J. Definitive surgical closure of enterocutaneous fistula: Outcome and factors predictive of increased postoperative morbidity. Colorectal Dis. 2014, 16, 209-218. [CrossRef] [PubMed]

5. Lauro, A.; Cirocchi, R.; Cautero, N.; Dazzi, A.; Pironi, D.; Di Matteo, F.M.; Santoro, A.; Faenza, S.; Pironi, L.; Pinna, A.D. Surgery for post-operative entero-cutaneous fistulas: Is bowel resection plus primary anastomosis without stoma a safe option to avoid early recurrence? Report on 20 cases by a single center and systematic review of the literature. Il G. Chir. 2017, 38, 185-198. [CrossRef] [PubMed]

6. Runström, B.; Hallböök, O.; Nyström, P.; Sjödahl, R.; Olaison, G. Outcome of 132 consecutive reconstructive operations for intestinal fistula-staged operation without primary anastomosis improved outcome in retrospective analysis. Scand. J. Surg. 2013, 102, 152-157. [CrossRef] [PubMed] 